\title{
Evaluating the historical treatment of female psychologists of distinction using citation analysis and textbook coverage
}

\author{
CINDELYN GRAY EBERTS \\ University of Illinois, Champaign, Illinois 61820 \\ and \\ PHILIP HOWARD GRAY \\ Montana State University, Bozeman, Montana 59717
}

\begin{abstract}
Five women and five men who were eminent in psychology half a century ago were compared for their treatment by historians, as well as the practical attention given their work, as evidenced by entries in Science Citation Index and Social Science Citation Index. The citation count seemed to give the fairest representation of relative attainments, and while no overt sexual discrimination was found in the history books, there was ample ground for complaint regarding the scholarship of persons (including females) writing these histories of psychology.
\end{abstract}

I am obnoxious to each carping tongue who says my hand a needle better fits. -Anne Bradstreet, 1650

Although women have recently become much interested in the contributions of women to society (Stineman, 1979), men have demonstrated a scholarly concern with eminent women dating as early as the publication of Giovanni Boccaccio's De Claris Mulieribus (Boccaccio, 1359/1964). Boccaccio begins with the mythical figure Eve and ends with his contemporary, Joanna I, the Norman-Anjou queen of Sicily, with whom Boccaccio is reputed to have had an affair (see footnote, p. 250, Boccaccio, 1359/1964).

None of the women in Boccaccio's work could properly be considered a scientist, but one of them, the Empress Constance, was the mother of Frederick II, the Holy Roman Emperor whose contribution to science, especially to the study of animal behavior, is well attested (Mountjoy, Bos, Duncan, \& Verplank, 1969). Although there appears to be no comprehensive survey of female scientists per se, the literature is growing (Davis, 1974; Handler, 1978; Rossiter, 1974). While there may be some difficulty assigning first honors for female contributions, we suggest that that role in psychology be given to Katherine Louisa, daughter of Baron Stanley of Alderley, who married John Russell (styled Viscount Amberley) and was the mother of Bertrand Russell (Gibbs, 1910-1959). Kate Amberley not only assisted Douglas Spalding in some of his pioneering research but was also, at times, an experimenter acting on her own (Gray, 1962, 1967).

Requests for reprints should be sent to the second author.
Being ourselves stimulated by the contemporary concern for women, we decided to find out how history has treated female psychologists who were distinguished in their own time. To answer the question, we selected a group of five women who were prominent in the affairs of psychology near the historical beginning of that science. We felt these were the first major contributors to psychology who were also female. We then selected a group of five men who could be considered to have equal contemporary standing. For this selection, we relied upon the Cattell rankings (Cattell, 1903, 1929) and corroborated the selection with the retrospective assessment of prominence to be found in the Annin, Boring, and Watson (1968) ratings (ABW).

All 10 of these psychologists are in Eminent Contributors to Psychology (Watson, 1974).

The hiatus between career zeniths of our psychologists and this study is ample time for scholarship to be exhibited. We are aware that historians tend to ignore geniuses who were scientific isolates (Esper, 1966, 1967; Gray, 1968, 1973), but our subjects were not isolates in their own lifetimes; on the contrary, they were very well received by their peers.

\section{METHOD}

\section{Subjects}

Christine Ladd-Franklin (b. 1847, d. 1930) is in the Dictionary of American Biography (1928-1937) (DAB) and the National Cyclopedia of American Biography Index (1979) (NCAB). She was a starred scientist in Cattell's American Men of Science (Visher, 1947). She received one or more honorary degrees and is included in both Who Was Who in America (Index: 1697-1981, 1981) (WWWA) and World Who's Who in Science (Debus, 1968) (WWWS). Of the 50 American psychologists whom Cattell ranked in his perceived order of distinction in 
1903, Ladd-Franklin was 19th. Her score on the ABW scale of recognition, on which 27 is maximum, was 22 .

Mary Whiton Calkins (b. 1863, d. 1930) is in NCAB but not in DAB. Hers is the second entry in A History of Psychology in Autobiography (Murchison, 1930-1936). She received one or more honorary degrees, was a starred scientist, was elected president of the American Psychological Association and the American Philosophical Society, and appears in WWWA but not in WWWS. She is the 12th psychologist on Cattell's list, and her ABW score was 20.

Margaret Floy Washburn (b. 1871, d. 1939) is in NCAB, DAB, and WWWA, but not WWWS. She received one or more honorary degrees, was a starred scientist, was a member of both the National Academy of Sciences and the Society of Experimental Psychology, served as president of the American Psychological Association, and appears in the second volume of $A$ History of Psychology in Autobiography (Murchison, 19301936). Although still in her early 30 s, she was ranked 42 nd on Cattell's list and her ABW score was 23.

June Etta Downey (b. 1875, d. 1932) appears only in DAB and WWWA. Like Washburn, she was a member of the Society of Experimental Psychologists after Titchener's death. She was a starred scientist. Cattell passed her over for his lists of 1909 and 1920 , but she was one of the 13 psychologists he added in 1926. Her ABW score was 14.

Leta (Stetter) Hollingworth (b. 1886, d. 1939) appears in DAB and WWWA. While she was included in American Men of Science, it was her husband, not she, who was the starred scientist. Her career reached its peak after the Cattell lists, but her ABW score was 12.

These women all had the benefits of being raised in upper class environments. Calkins, Washburn, and Hollingworth grew up in clerical families; Ladd-Franklin's father was a prominent merchant, and Downey's was a lawyer and member of Congress. Downey and Hollingworth were of frontier background, but little is known of their genealogy except that, in addition to their respective Irish and German ethnicity, each appeared to have some British ancestry. Washburn, Calkins, and LaddFranklin were of New England Puritan stock. In doing as much genealogical research as was feasible, we found an interesting line for Christine Ladd. Besides being a fifth cousin at one remove to George Trumbull Ladd (Ladd, 1890), she has a descent from the Reverend John Maverick and his wife Mary Gye (Noyes, Libby, \& Davis, 1928-1939, pp. 263 \& 470). This Mary Gye was descended from Henry II of England and the Norman conquerors (Weis \& Sheppard, 1976). Thus Christine Ladd-Franklin was a genetic relative of that Joanna I whose lover wrote the first encyclopedia on women.

Edmund Clark Sanford (b. 1859, d. 1924) is in NCAB, DAB, and WWWA. He received one or more honorary degrees, was a starred scientist, and was president of the American Psychological Association. He was 11th on Cattell's first list and had an ABW score of 20.

Edward Wheeler Scripture (b. 1864, d. 1945) is in NCAB and WWWA and appeared in A History of Psychology in Autobiography (Murchison, 1930-1936). He was 18th on Cattell's 1903 list and had an ABW score of 23.

Walter Bowers Pillsbury (b. 1872, d. 1960) is in NCAB, WWWA, and WWWS. He received one or more honorary degrees, was a starred scientist, belonged to the National Academy of Sciences and the Society of Experimental Psychologists, served as president of the American Psychological Association, and appears in A History of Psychology in Autobiography (Murchison, 1930-1936). He was 37 th on Cattell's first list. His ABW score was 21 .

Walter Fenno Dearborn (b. 1878, d. 1955) is seen in NCAB and WWWA. He received one or more honorary degrees and was a starred scientist and a fellow of the American Academy of Arts and Science. He was added to Cattell's lists in 1920 and had an ABW score of 12 .
Warner Brown (b. 1882, d. 1956) is in NCAB, was a starred scientist, and belonged to the Society of Experimental Psychologists. He was added to the Cattell lists in 1926 and had an ABW score of 11 .

Although we selected these men on the basis of how closely they compared with our women subjects, using the Cattell rankings and the ABW scores, we are pleased to note how closely the two groups also compare in genealogical and familial aspects. All the men were raised in upper class families, although only one of them (Pillsbury) appears to have had a clergyman father. Brown was primarily of Dutch and German ancestry (de Bruyn was a colonial family in New York) but evidently had some British ancestry also. Dearborn, Pillsbury, and Scripture were definitely of New England Puritan origins, and Sanford may have been.

An analysis of behavior becomes more nearly adequate as we take account of the genotypic and phenotypic antecedents. We now know that family background can account for nearly as much as $50 \%$ of the variance in occupational success (Jencks, Bartlett, Corcoran, Crouse, Eaglesfield, Jackson, McClelland, Mueser, Olneck, Schwartz, Ward, \& Williams, 1979), and it has been suggested that a "hereditary genius" component may account for the remaining variance that differences in IQ cannot (Gray, Note 1). We have therefore felt constrained to adopt the analytical model of the animal behaviorist, who would not dare fail to specify all that he knew about the antecedents of his subjects. The fact that most psychologists (including, unfortunately, historians) are loathe to be this exacting does not mean that they are correct.

\section{Procedure}

Eminence is measured in different ways according to occupations and periods. Entertainers are ranked on the basis of their popularity, or "box-office draw," which involves judgments rendered by the common people. Politicians need to be attractive to their constituents first and to the media second, with a final evaluation by scholars. Professional people, especially scientists, are evaluated by their peers in their own lifetimes. The results of peer acceptance are seen in the initiation into scholarly societies and election to offices, to be followed by such events as honorary degrees and inclusion in biographical sources. After death, if the scientist has not attained a culture-hero status, such as Darwin or Einstein, evaluation will be continued by professional historians with their production of historical textbooks. While this process of continuous evaluation can be derivative and allelomimetic, as it is in psychology, it is also deliberative and executed with the manifest intent of giving or denying a scientist his or her place in history.

We scanned 20 histories of psychology, ranging in publication date from 1950 to 1976 , seeking an answer to the question, how have eminent female psychologists been treated when compared with equally eminent male psychologists? ${ }^{1}$ In our search, each line or partial line discussing 1 of the 10 subjects counted as 1 point and incidental mentions or references to the subject's publications counted as .5 point.

When the machine tabulation of references in professional science journals was introduced in 1961, we gained another, and more facile, method of evaluating eminence. Now called citation analysis, this method is rather less deliberative, but perhaps neither derivative nor allelomimetic, inasmuch as it reflects the decisions of professionals as to what is relevant to their current productions. The advantages and problems of using citation analysis to evaluate scientific eminence has been discussed at length by Gray (1974). To complement the history textbook points, we counted first-author references from 1961 through 1978 in Science Citation Index and Social Science Citation Index (Garfield, 1979), being careful not to include the duplications that sometimes occurred without indication after 1973. Each of us independently counted citations and then compared and reconciled the results. We believe we caught most if not all 
of the variants that make citation analysis so difficult. Eminent Contributors to Psychology (Watson, 1974) was helpful, with its bibliography of primary references, although we could not help noticing the omissions by that reference source, such as the frequently cited paper Downey (1926) did on the genetic influence of the handclasp.

\section{RESULTS AND DISCUSSION}

Our sense of proportion is least disturbed by the citations count. When ranked, the males and females do not separate into statistically different groups using the Mann-Whitney U test (Siegel, 1956). With a range of citations from 24 for Ladd-Franklin to 101 for Washburn, it is obvious that all these once eminent scientists still command attention from the working scientists of today. However, while the textbook analysis did not separate the males and females into statistically different groups using the Mann-Whitney $U$ test, it did yield considerable variability (Table 1 ).

We found no clear evidence of sex discrimination. Nonetheless, our intuitive feeling is that gross deficiencies exist in the work and attitudes of our historians. Perhaps we are guilty of expecting more for the people we had elected to study. This was true especially for the women psychologists, whom we considered to be among the most prominent women scientists of their time, although the Dictionary of Scientific Biography (Gillispie, 19701980 ), recently completed under the auspices of the Council of Learned Societies, mentions not a single one of our subjects, man or woman, adding one more fault to other complaints about Gillispie (Fleming, Needham, Grant, \& Roger, 1980).

If it can be argued that including at least some mention of the leading female scientists is obligatory in the history of a science, then most of the textbooks we searched cannot be recommended. Nine of them carry no mention of our five female psychologists, as far as we could tell.

Table 1

\begin{tabular}{lrrr}
\hline \multicolumn{1}{c}{ Name } & Citations & Points \\
\hline & \multicolumn{3}{c}{ Women } \\
Calkins & 38 & 125.5 \\
Downey & 48 & 6.5 \\
Hollingworth & 49 & 5.0 \\
Ladd-Franklin & 24 & & 2.0 \\
Washburn & 101 & & 50.0 \\
& & Men & \\
Brown & 61 & & 2.0 \\
Dearborn & 74 & & 12.5 \\
Pillsbury & 81 & & 49.0 \\
Sanford & 38 & 75.5 \\
Scripture & 54 & 391.5 \\
\hline
\end{tabular}

Note-Citations are first-author counts in Science Citation Index and Social Science Citation Index (Garfield, 1979). Points are lines, or partial lines, counted in 20 history of psychology textbooks.
Given that the 3 female-authored or co-authored histories treated our female subjects no better than the 17 solely male-authored histories did (worse, actually), the usual sexual-bias argument does not seem to apply here. If any discrimination is being exhibited, it is perhaps the attitude found among well-educated and well-reared individuals that one simply does not expect much by way of genius from the lower classes, from ethnic minorities, or from women. That attitude may be changing, even if our study shows no such change, but we are, for the time being, skeptical.

We are skeptical because the strongest foe of scholarship is not ignorance in and of itself. Instead, it is the set of predispositions that scholars are probably not even aware they harbor. And it goes almost without saying that the most persistent enemy is the unseen, unsuspected one.

\section{REFERENCE NOTE}

1. Gray, P. H. Genetic and genealogical implications for success, including the American presidents. In Determinants of Success, P. H. Gray (Chair), Symposium given at the annual meeting of the American Psychological Association, Montreal, Canada, 1980.

\section{REFERENCES}

Annin, E. L., Boring, E. C., \& Watson, R. I. Important psychologists, 1600-1967. Journal of the History of the Behavioral Sciences, 1968, 4, 303-315.

Boccaccro, G. [Concerning famous women] (G. A. Guarino, trans.). London: Allen \& Unwin, 1964. (Originally published, 1359.)

Cattell, J. M. Statistics of American psychologists. American Journal of Psychology, 1903, 14, 310-328.

Cattell, J. M. Psychology in America. New York: Science Press, 1929.

DAvis, A. B. Bibliography on women. New York: Science History Publications, 1974.

Desus, A. G. (Ed.). World who's who in science. Chicago: Marquis, 1968.

Dictionary of American Biography (20 vols.). New York: Scribner, 1928-1937.

Downey, J. E. Further observations on the manner of clasping the hands. American Naturalist, 1926, 60, 387-391.

Esper, E. A. Max Meyer: The making of a scientific isolate. Journal of the History of the Behavioral Sciences, 1966, 4, 341-356.

Esper, E. A. Max Meyer in America. Journal of the History of the Behavioral Sciences, 1967, 5, 107-131.

Fleming, D., Needham, J., Grant, E., \& Roger, J. The DSB: A review symposium. Isis, 1980, 71, 633-652.

Garfield, E. Citation indexing. Its theory and application in science, technology, and humanities. New York: Wiley Interscience, 1979.

GibBs, V. (Ed.). The complete peerage of England Scotland Ireland Great Britain and the United Kingdom extant extinct or dormant (13 vols.). London: St. Catherine Press, 1910-1959.

Gillispie, C. C. (Ed.). Dictionary of scientific biography (16 vols.). New York: Scribner, 1970-1980.

GrAy, P. H. Douglas Alexander Spalding: The first experimental behaviorist. Journal of General Psychology, 1962, 67, 299-307. 
Gray, P. H. Spalding and his influence on research in developmental behavior. Journal of the History of the Behavioral Sciences, 1967, 5, 168-179.

Gray, P. H. The early animal behaviorists: Prolegomenon to ethology. Isis, 1968, 59, 372-383.

GRAY, P. H. Comparative psychology and ethology: A saga of twins reared apart. Annals of the New York Academy of Sciences, 1973, 223, 49-53.

Gray, P. H. Science citations salaries. Bozeman, Mont: N. P., 1974.

Handler, P. Women scientists: Steps in the right direction. The Sciences, 1978, 18, 6-9.

Jencks, C., Bartlett, S., Corcoran, M., Crouse, J., Eaglesfield, D., Jackson, G., McClelland, K., Mueser, P., Olneck, M., Schwartz, J., Ward, S., \& Williams, J. Who gets ahead? The determinants of economic success in America. New York: Basic Books, 1979.

LADD, W. The Ladd family. New Bedford, Mass: Anthony, 1890. Mountuoy, P. T., Bos, J. H., Duncan, M. O., \& Verplank, R. B. Falconry: Neglected aspect of the history of psychology. Journal of the History of the Behavioral Sciences, 1969, 5, 59-67.

Murchison, C. A history of psychology in autobiography (Vol. 1-3). New York: Appleton-Century-Crofts, 1930-1936.

National Cyclopedia of American Biography Index. New York: White, 1979.

Noyes, S., Libby, C. T., \& DAvis, W. G. Genealogical dic- tionary of Maine and New Hampshire (5 parts). Portland, Maine: N. P., 1928-1939.

Rossiter, M. W. Women scientists in America before 1920. American Scientist, 1974, 62, 312-323.

Siegel, S. Nonparametric statistics for the behavioral sciences. New York: McGraw-Hill, 1956.

Stineman, E. Women's studies: $A$ recommended bibliography. Littleton, Colo: Libraries Unlimited, 1979.

VISHER, S. S. Scientists starred 1903-1943 in "American Men of Science": A study of collegiate and doctoral training, birthplace, distribution, backgrounds, and developmental influences. Baltimore, Md: Johns Hopkins Press, 1947.

Watson, R. I. Eminent contributors to psychology (Vol. 1). New York: Springer, 1974.

WeIs, F. L., \& ShEPPARD, W. L. Ancestral roots of sixty colonists who came to New England between 1623 and 1650 (5th ed.). Baltimore, Md: Genealogical, 1976.

Who Was Who in America: Index 1607-1981. Chicago: Marquis, 1981.

\section{NOTE}

1. A complete list of the histories used may be obtained from the authors.

(Received for publication December 23, 1981.) 